\title{
PIK3C2G Gene
}

National Cancer Institute

\section{Source}

National Cancer Institute. PIK3C2 G Gene. NCI Thesaurus. Code C102945.

This gene is involved in the phosphorylation of phosphoinositol. 